\title{
Power ultrasound as a tool to improve the processability of protein-enriched fermented milk gels for Greek yogurt manufacture
}

\author{
Adrian Körzendörfer, ${ }^{*}$ Johannes Schäfer, Jörg Hinrichs, and Stefan Nöbel† \\ Institute of Food Science and Biotechnology, University of Hohenheim, Garbenstr. 21, 70599 Stuttgart, Germany
}

\section{ABSTRACT}

One approach to avoid production of acid whey during the manufacture of high-protein yogurt and related products is to concentrate the milk before fermentation. However, the resultant gels are firm so that stirring in the tank and further processing are difficult on an industrial scale. We hypothesize that power ultrasound (US) during fermentation softens the gel because sound waves cause cavitation and strong shear forces in the fluid. Skim milk was standardized to different protein contents up to $12 \%$, heated $\left(85^{\circ} \mathrm{C}\right.$, $30 \mathrm{~min}$ ), and acidified with thermophilic or mesophilic starter cultures. An excessive increase in gel firmness as a function of protein content was detected. In the next series of experiments, US was applied during fermentation. Milks (10\% protein) were acidified at $43.5^{\circ} \mathrm{C}$ and sonicated from $\mathrm{pH} 5.8$ to 5.1 with a sonotrode $(20$ $\mathrm{kHz}, 20 \mathrm{~W})$. Immediately after fermentation, gels were agitated using a rheometer with a vane geometry. The maximum torque required to break the gel was reduced by $75 \%$ following US, and gel firmness was reduced by $80 \%$. Gels were then processed into stirred yogurt and analyzed. Sonicated samples were smoother with fewer large aggregates. Confocal laser scanning microscopy images suggested a less cohesive structure and more compact microgel particles, resulting in reduced viscosity. We concluded that US is a promising tool to weaken the gel and facilitate further processing. This enables new approaches for the manufacture of Greek yogurt, particularly in regard to avoiding production of acid whey and developing products with novel textures. Key words: strained yogurt, Greek-style yogurt, gelation, sonication

Received February 25, 2019.

Accepted May 4, 2019.

*Corresponding author: adrian.koerzendoerfer@uni-hohenheim.de

$\dagger$ Current address: Federal Research Institute of Nutrition and Food, Max Rubner-Institut, Hermann-Weigmann-Str. 1, 24103 Kiel, Germany.

\section{INTRODUCTION}

There is still a high demand for concentrated fermented milks such as Greek yogurt and skyr. Considerable research has been published on the health benefits of milk proteins in recent years (Fekete et al., 2013). Nutrition-conscious consumers appreciate the high protein content (up to 10\%) in products that commonly contain no fat (Tamime et al., 2014). The consistency is creamy and thick without the need for stabilizers (Desai et al., 2013; Brown and Chambers, 2015). Typically, the milk is acidified in tanks, forming a gel that is broken up by stirring and concentrated by centrifugation or ultrafiltration (Abu-Jdayil et al., 2002; Özer, 2006). This process generates large amounts of acid whey that is undesired because of environmental concerns (Mawson, 1994; Chen et al., 2018; Erickson, 2017). Concentrating the milk after fermentation to a protein content of $8 \%$ produces approximately $1.3 \mathrm{~kg}$ of acid whey per $\mathrm{kg}$ of yogurt (Jørgensen et al., 2019).

One approach to avoid acid whey is to concentrate the milk before fermentation by ultrafiltration (Özer et al., 1999; Uduwerella et al., 2018) or microfiltration (Jørgensen et al., 2015; Schäfer et al., 2019). Alternatively, protein powders such as milk protein concentrate and micellar casein concentrate can be added (Bong and Moraru, 2014; Agarwal et al., 2015; Uduwerella et al., 2017). However, apart from flavor issues, the resultant gels are firm (Mistry and Hassan, 1992), which leads to technical problems during commercial production; stirring in the tank, draining, and further processing become difficult or impossible. Gels from concentrates exhibit a high interconnectivity so that the reduction of microgel particle size is impaired. Hence, it is also challenging to produce a smooth texture (Krzeminski et al., 2013; Jørgensen et al., 2015). Potential strategies include adjusting the formulation and mechanical post-processing (Sodini et al., 2004; Jørgensen et al., 2015; Mokoonlall et al., 2016a; Mahomud et al., 2017). In addition to conventional shear devices, a hydrodynamic cavitator was reported to modify the rheological properties of Greek yogurt made from concentrates (Meletharayil et al., 2016). Cavitation is the formation 
and subsequent collapse of bubbles filled with vapor or dissolved gas, and it occurs when the local pressure falls sufficiently far below the saturated vapor pressure (Brennen, 1995). It can be generated by the passage of the liquid through a constriction such as a throttling valve (Gogate and Pandit, 2005).

Power ultrasound (US) using frequencies mainly from 20 to $40 \mathrm{kHz}$ is another technology to generate (acoustic) cavitation (Mason and Peters, 2002). Unlike conventional shear devices, applying power US does not require the medium to be pumped, which is not possible during fermentation. In yogurt manufacturing, sonication of the milk before or just after inoculation can result in beneficial physical properties (Chandrapala and Leong, 2015). In contrast, gel firmness was decreased when the milk was sonicated during the gelation in an ultrasonic water bath (Körzendörfer et al., 2017). However, the effect of power US during the gelation of high-protein milk has not been reported yet. We hypothesize that power US during fermentation is a tool to soften the milk gel. Several studies have reported the manufacture of high-protein Greek yogurt from preconcentrated milk. However, none have addressed the issue that fermented concentrates have excessive firmness that results in technical and sensory problems. In this study, we focused on the fermentation of milk concentrates and the applicability of power US during acidification, targeting softening of the gel during fermentation and, thus, facilitating further processing such as stirring and shearing to achieve a smooth texture. In a preliminary experiment, milks were standardized to different protein contents up to $12 \%$ and acidified with thermophilic (yogurt) or mesophilic (curd cheese/quarg) starter cultures, respectively. The increase in gel firmness as a function of the protein content was studied to estimate the processability on an industrial scale. Afterward, we applied power US during the fermentation of protein-enriched milk and then analyzed the physical properties of set gels and corresponding stirred yogurts.

\section{MATERIALS AND METHODS}

\section{Raw Materials and Milk Standardization}

Bovine raw milk was provided weekly by an agricultural experiment station (Meiereihof, University of Hohenheim, Stuttgart, Germany), skimmed at $55^{\circ} \mathrm{C}$ (SA 10; Frautech S.r.l., Schio, Italy), and pasteurized at $74^{\circ} \mathrm{C}$ for $30 \mathrm{~s}$. Dry matter, protein, and fat contents were analyzed with a Fourier transform infrared (FTIR) spectrometer (LactoScope FTIR Advance; Delta Instruments, Drachten, the Netherlands). The lactose content was determined by an accredited laboratory
(Landwirtschaftliches Zentrum Baden-Württemberg, Wangen, Germany) using an enzymatic method (DIN 10344; BVL, 1980). Calcium was determined by means of a complexometric method (C 10.6.8; VDLUFA, 2003). All chemical analyses were performed in triplicate. The protein content was standardized using milk protein powder (TMP 80; Milei GmbH, Leutkirch, Germany) derived from ultrafiltered skim milk. Table 1 shows the chemical composition of the skim milk and milk protein powder. To investigate the correlation between protein content and firmness of the fermented set gel, milks were standardized to $3.5,4.0,6.0,8.0,10.0$, and $12.0 \%$ (wt/wt) protein.

\section{Milk Pretreatment and Starter Cultures}

Standardized skim milks ( $3 \mathrm{~L}$ ) were heated to $\geq 85^{\circ} \mathrm{C}$ for $30 \mathrm{~min}$ in a water bath $\left(95^{\circ} \mathrm{C}\right.$; AEJ $6-5$; Aerne Analytic e. K., Weißenhorn, Germany) to denature the whey proteins $(>90 \%)$ and then cooled to $6^{\circ} \mathrm{C}$ in iced water. Fermentations were carried out under mesophilic or thermophilic conditions. Choozit 230 (Danisco Deutschland GmbH, Niebüll, Germany) containing Lactococcus lactis ssp. lactis and Lactococcus lactis ssp. cremoris was used for mesophilic fermentations. Thermophilic fermentations were performed with YC-471 (Chr. Hansen A/S, Hørsholm, Denmark) containing Lactobacillus delbrueckii ssp. bulgaricus and Streptococcus thermophilus. Before every experiment, $125 \mathrm{~g}$ (Choozit 230) or $250 \mathrm{~g}$ (YC-471) of the frozen starter culture was diluted with $1,000 \mathrm{~g}$ of skim milk $\left(6^{\circ} \mathrm{C}\right)$ to ensure a balanced distribution of the species, respectively. Stock solutions were thawed at room temperature with occasional stirring before inoculation.

\section{Yogurt Fermentation}

Polypropylene containers (diameter $=102 \mathrm{~mm}$, length $=155 \mathrm{~mm}$ ) were filled with $900 \mathrm{~g}$ of milk preheated to fermentation temperatures $\left(43.5\right.$ or $\left.22.5^{\circ} \mathrm{C}\right)$ and placed in a tempered water bath (K25; Huber Kältemaschinenbau GmbH, Offenburg, Germany). After temperatures had equilibrated, milks were inoculated with $2.25 \mathrm{~mL}$ of starter culture stock solution (i.e., $0.05 \%$ in total) and fermented until $\mathrm{pH} 4.6$ at $22.5^{\circ} \mathrm{C}$ (mesophilic) or $43.5^{\circ} \mathrm{C}$ (thermophilic), respectively. Acidification was continuously monitored with $\mathrm{pH}$ sensors (SE555X/2NMSN; Knick Elektronische Messgeräte GmbH \& Co. KG, Berlin, Germany; software: DAQ Factory Express; Azo Inc., Memphis, TN). During fermentation, yogurt samples were temporarily sonicated as described in the Sonication section below. Fermentations were stopped at $\mathrm{pH} 4.6$ by immersing the containers in iced water for $60 \mathrm{~min}$. Samples were stored overnight at $10^{\circ} \mathrm{C}$ until 
Table 1. Chemical composition of pasteurized skim milk and milk protein powder ${ }^{1}$

\begin{tabular}{lccccr}
\hline Item & Protein (\%) & Fat $(\%)$ & Lactose $(\%)$ & $\mathrm{Ca}^{2+}(\mathrm{mg} / \mathrm{g})$ & $\mathrm{DM}(\%)$ \\
\hline Skim milk & 3.4 & 0.1 & 5.1 & 1.23 & 9.3 \\
Milk protein powder $^{2}$ & 79.9 & 1.1 & 7.3 & 22.06 & 6.7 \\
\hline
\end{tabular}

${ }^{1}$ Mean values calculated from 4 independent replicates.

${ }^{2}$ According to manufacturer's specification (TMP 80; Milei GmbH, Leutkirch, Germany).

further analysis and processing. The number of independent repetitions of the experiments was $\geq 3$.

\section{Sonication}

Power US was generated by an ultrasonic device (Sonopuls HD 2200; Bandelin Electronic GmbH \& Co. KG, Berlin, Germany) with a nominal maximum ultrasonic output of $200 \mathrm{~W}$. The ultrasonic generator (GM 2200) transforms low-frequency voltage $(50 \mathrm{~Hz})$ into high-frequency voltage $(20 \mathrm{kHz})$. Electrical voltage from the generator is transformed into mechanical vibrations of $20 \mathrm{kHz}$ (ultrasonic converter: UW 2200). A booster horn ( $\mathrm{SH} 213 \mathrm{G}$ ) amplifies the vibrations that are finally transmitted into the sample by the probe equipped with a titanium flat tip (TT13; diameter $=13$ $\mathrm{mm}$, length $=5 \mathrm{~mm}$ ). The amplitude was set to $100 \%$, which corresponds to a displacement of $165 \mu \mathrm{m}$ (peakto-peak). During fermentation, milks were sonicated from $\mathrm{pH} 5.8$ to 5.1 , the range in which gelation occurs. The US waves were introduced by immersing the probe in the milk to a depth of approximately $15 \mathrm{~mm}$. To avoid an increase in temperature, sonication was performed in pulse mode with a cycle time of $1 \mathrm{~s}(0.2 \mathrm{~s}$ on, $0.8 \mathrm{~s}$ off). The immersion point was carefully changed during treatment to ensure a homogeneous distribution of the sound waves. Sonication experiments were only performed with skim milk standardized to a protein content of $10 \%$ (wt/wt) under thermophilic conditions (i.e., starter culture YC-471).

Additionally, ultrasonic intensity was determined using a calorimetric method described by Tiwari et al. (2008). The ultrasonic power $P$ was calculated using demineralized water $(0.25 \mathrm{~kg})$ according to

$$
P=m c_{p}\left(\frac{\mathrm{d} T}{\mathrm{~d} t}\right)_{t=0}
$$

where $m$ is the mass, $c_{p}$ is the specific heat of water $(4.18$ $\left.\mathrm{kJ} \cdot \mathrm{kg}^{-1} \cdot \mathrm{K}^{-1}\right)$, and $(\mathrm{d} T / \mathrm{d} t)$ is the change in temperature over time $\left(\mathrm{K} \cdot \mathrm{s}^{-1}\right)$. Afterward, ultrasonic intensity $(U I)$ was determined according to

$$
U I=\frac{4 P}{\pi d^{2}},
$$

where $d$ is the diameter of the probe. The sonication parameters above resulted in an ultrasonic power, $P$, of $20 \mathrm{~W}$ and $U I$ of $15 \mathrm{~W} \cdot \mathrm{cm}^{-2}$.

\section{Agitation Test}

Agitation tests were conducted to describe the fracture behavior during stirring of the set milk gel after acidification. This test served to estimate the processability of the gel in a large-scale fermentation tank. To avoid disruptions of the protein network, measurements were carried out in the fermentation containers. A rheometer (AR2000ex; TA Instruments, New Castle, DE) was equipped with a vane geometry (4 paddles, diameter $=15 \mathrm{~mm}$, length $=28 \mathrm{~mm}$ ) that was immersed directly into the warm $\left(\sim 40^{\circ} \mathrm{C}\right)$ set milk gel at the end of the fermentation. The rotational velocity of the vane was linearly increased for $90 \mathrm{~s}$. In total, 4 complete revolutions were done and the required torque was recorded. Three independent measurements were performed in one container.

\section{Gel Firmness}

Penetration tests of set milk gels were accomplished $1 \mathrm{~d}$ after fermentation by using a universal testing machine (5944; Instron, Norwood, MA; load cell: $50 \mathrm{~N}$; software Bluehill 3, Instron). The sample temperature was $10^{\circ} \mathrm{C}$ and 7 measuring repetitions were done per container using a cylindrical probe (10 $\mathrm{mm}$ diameter). The test speed was set to $0.5 \mathrm{~mm} / \mathrm{s}$ for $30 \mathrm{~s}$ and the force was recorded. Gel firmness was defined as the first maximum force.

\section{Stirred Yogurt Production}

To produce the stirred yogurt, we modified the method of Mokoonlall et al. (2016b). After the agitation tests and firmness measurements, set yogurt gels were broken with a spoon, manually stirred for $1 \mathrm{~min}$, and then sheared at approximately $10^{\circ} \mathrm{C}$ with a large syringe (internal diameter $=58 \mathrm{~mm}$, length $=290 \mathrm{~mm}$; Hausammann \& Co AG, Zürich, Switzerland) through a nozzle (internal diameter $=3 \mathrm{~mm}$, length $=25 \mathrm{~mm}$ ). The piston was moved by the universal testing machine (5944; Instron; load cell: $2 \mathrm{kN}$ ) to ensure a constant 
flow rate of $40 \mathrm{~mL} / \mathrm{s}$, which corresponds to a representative shear rate $\left(\dot{\gamma}_{\text {rep }}\right)$ of $15,100 \mathrm{~s}^{-1}$ within the nozzle:

$$
\dot{\gamma}_{r e p}=(4 \dot{V}) / \pi r^{3},
$$

where $\dot{V}$ is the volume flow $\left(\mathrm{m}^{3} / \mathrm{s}\right)$ and $r$ the radius of the nozzle $(\mathrm{m})$. Stirred yogurts were stored in containers $(500 \mathrm{~mL})$ at $10^{\circ} \mathrm{C}$ until further analyses (waterholding capacity, transmission images, confocal laser scanning microscopy, laser diffraction). For rheological measurements, separate samples in glass jars $(100 \mathrm{~mL}$, 3 jars per sample) were stored for $7 \mathrm{~d}$ at $10^{\circ} \mathrm{C}$ and not disturbed until analyses to allow rebodying.

\section{Water-Holding Capacity}

Stirred yogurt samples (40 g) were centrifuged (Biofuge primo R; Heraeus Holding GmbH, Hanau, Germany) at $1,000 \times g$ and $10^{\circ} \mathrm{C}$ for $10 \mathrm{~min}$. After removing the supernatant, the pellet weight was recorded. Measurements were performed in triplicate. The waterholding capacity (WHC) was calculated as follows:

$$
\operatorname{WHC}(\%)=\frac{\text { pellet weight }(\mathrm{g})}{\text { initial yogurt }(\mathrm{g})} \times 100 \text {. }
$$

\section{Transmission Images: Texture and Large Particles}

Transmission images served to evaluate the texture of stirred yogurts with regards to visual graininess. Additionally, large particles with diameter $\geq 0.9 \mathrm{~mm}$ (15 pixels) were quantified by means of image analysis according to previous studies (Nöbel et al., 2016). Briefly, a thin layer $(1.2 \mathrm{~mm})$ of the yogurt sample was scratched out with a scraper and metal bar spacers on a glass plate, from which transmission images (source of light: Comic Master Tracer LED-A4, Too Marker Products Inc., Tokyo, Japan) were taken using a digital camera (8-bit grayscale; MicroPublisher 3.3 RTV, QImaging, Surrey, Canada). One image (120 $\times 90 \mathrm{~mm}$ ) represented approximately $13 \mathrm{~g}$ of yogurt. Particles were classified and counted using Matlab 8.3 (R2014a) and Matlab's Image Processing Toolbox 8.2 (The MathWorks Inc., Natick, MA). Particle numbers are given per $100 \mathrm{~g}$ of yogurt. Data were obtained from at least 10 independent images per sample.

\section{Laser Diffraction Spectroscopy}

Particle size distributions of small microgel particles (diameter $<0.5 \mathrm{~mm}$ ) were determined by means of static light scattering (LS 13320; Beckman-Coulter Inc., Miami, FL) as described by Mokoonlall et al. (2015). Yogurt samples were diluted with demineralized water $(6 \% \mathrm{wt} / \mathrm{wt})$ and stirred for $15 \mathrm{~min}$ at 150 rpm. Approximately $1 \mathrm{~mL}$ of the diluted sample was added to the dispersion unit (obscuration: 14-16\%). Three successive runs were performed of each sample. Measurements were repeated 3 times and the volumeweighted 10 th, 50 th, and 90 th percentiles $\left(\boldsymbol{d}_{\mathbf{1 0}}, \boldsymbol{d}_{\mathbf{5 0}}, \boldsymbol{d}_{\mathbf{9 0}}\right)$ were calculated.

\section{Rheological Characterization}

Flow properties of standardized, heated skim milks differing in protein content were measured at $10^{\circ} \mathrm{C}$ using a rheometer (MCR 502; Anton Paar GmbH, Graz, Austria) equipped with a coaxial double-gap geometry (DG27). The shear rate was linearly increased from 0 to $500 \mathrm{~s}^{-1}$ and the apparent viscosity $(\eta)$ at $500 \mathrm{~s}^{-1}$ was calculated.

Stirred yogurt samples were analyzed $7 \mathrm{~d}$ after the mechanical treatment at $10^{\circ} \mathrm{C}$ with a coaxial cylinder geometry (CC27). After an equilibration time of 10 min, storage modulus $\left(\mathrm{G}^{\prime}\right)$ and phase angles $(\delta)$ were determined by means of oscillating measurements in the linear viscoelastic region (shear stress, $\gamma=0.0025$ ) by performing a 30-s time sweep at a constant frequency of $10 \mathrm{rad} / \mathrm{s}$. Flow curves were measured in successive rotational measurements using the same sample. The shear rate was linearly increased from 0 to $500 \mathrm{~s}^{-1}$ within 3 min. After a hold step $\left(3 \mathrm{~min}, 500 \mathrm{~s}^{-1}\right)$, the shear rate was linearly decreased to $0 \mathrm{~s}^{-1}$ within $3 \mathrm{~min}$. Measurements were repeated 3 times and the apparent viscosity at a shear rate of $100 \mathrm{~s}^{-1}\left(\eta_{100}\right)$ was calculated; this parameter is associated with perceived oral viscosity (Skriver et al., 1999).

\section{Confocal Laser Scanning Microscopy}

The microstructure of stirred yogurts was visualized by confocal laser scanning microscopy (CLSM). The protein phase was stained with $35 \mu \mathrm{L}$ of rhodamine B solution (0.016\% wt/wt, $479 \mathrm{~g} \mathrm{~mol}^{-1}$, Art.-No. 107599, CAS 81-88-9, Merck KGaA, Darmstadt, Germany). Four specimens of each sample were prepared according to Heilig et al. (2009). Images were taken using a microscope (Eclipse-C1; Nikon GmbH, Düsseldorf, Germany) equipped with a $63 \times$ oil immersion objective, controlled via the software NIS-Elements Confocal (Nikon $\mathrm{GmbH}$ ). Two images were taken at $10^{\circ} \mathrm{C}$ of each specimen. Finally, the most representative images were selected. 


\section{Statistical Analyses}

Statistical analyses were conducted with SigmaPlot (v. 12.5; Systat Software Inc., San Jose, CA). The Mann-Whitney U test served to evaluate the effect of vibrations between 2 groups (control versus sonicated sample). A significance level of $\alpha=0.05$ was chosen in all cases. Results are given as arithmetic means and standard errors.

\section{RESULTS AND DISCUSSION}

\section{Effect of Protein Content}

Our intention was to study the effect of different protein contents, covering the range from conventional yogurts to high-protein products. As the milk protein powder used for standardization was derived from ultrafiltration, milks differing in protein content corresponded chemically to UF retentates, with an unaltered ratio between caseins and whey proteins. Other ingredients were similar across samples (Table 2).

Flow Behavior of Milk Concentrates. Figure 1a shows the apparent viscosity of protein-enriched skim milks as a function of protein content. In the range from 3.5 to $12.0 \%$ (wt/wt) protein, apparent viscosity increased disproportionately from 4.2 to $76.7 \mathrm{mPa} \cdot \mathrm{s}$, and data could be fitted by a power function $\left(\mathrm{R}^{2}>\right.$ 0.99). This behavior was reported in previous studies with microfiltered and ultrafiltered milk concentrates (Solanki and Rizvi, 2001; Aaltonen, 2012). According to de Kruif (1998), at low to medium concentrations, casein micelles act as hard spheres and viscosity increases moderately with casein content. If a certain volume fraction is reached, casein micelles interact more strongly with each other (Hinrichs, 1999). During these interactions, an overlapping of the hairy layers occurs and a strong increase in viscosity is observed (Hinrichs, 2000; Bouchoux et al., 2009; Dahbi et al., 2010). The flow behavior of the protein-enriched skim milks was Newtonian up to a protein content of $10 \%$ (wt/wt), whereas shear-thinning behavior was observed at a protein content of $12 \%$ (wt/wt) (data not shown). The latter phenomenon is not fully understood, but Bouchoux et al. (2009) proposed that the behavior of casein micelles at high concentrations deviates slightly from that of a hard sphere. Micelles are deformed and alignment along the flow direction occurs, resulting in a shear-thinning behavior.

Fermentation Characteristics. Table 2 shows the fermentation characteristics of skim milks acidified at 22.5 and $43.5^{\circ} \mathrm{C}$. Generally, fermentations with the mesophilic starter culture at $22.5^{\circ} \mathrm{C}$ resulted in much longer fermentation times than those performed at $43.5^{\circ} \mathrm{C}$ with the thermophilic starter culture. Regardless of the fermentation temperature and starter culture, an increase in protein content was accompanied by an increase in fermentation time: $3 \mathrm{~h} 34 \mathrm{~min}$ (3.5\% protein) and $4 \mathrm{~h}$ $23 \mathrm{~min}$ (10\% protein) at a fermentation temperature of $43.5^{\circ} \mathrm{C}$ (1.2-fold increase), and $12 \mathrm{~h} 40 \mathrm{~min}$ (3.5\% protein) and $25 \mathrm{~h} 35 \mathrm{~min}(10 \%$ protein) at a fermentation temperature of $22.5^{\circ} \mathrm{C}$ (2-fold increase). The increase in fermentation time was more pronounced at $22.5^{\circ} \mathrm{C}$, as reported by Biliaderis et al. (1992) and Mistry and Kosikowski (1985b). The strong increase in fermentation time as a function of protein content during the acidification of milk concentrates is in accordance with the findings of other groups (Mistry and Kosikowski, 1985a,b; Srilaorkul et al., 1989), who explained this behavior as follows. Higher protein contents result in an

Table 2. Chemical composition and fermentation characteristics of milks differing in protein content acidified at $43.5^{\circ} \mathrm{C}$ and $22.5^{\circ} \mathrm{C}$, respectively

\begin{tabular}{|c|c|c|c|c|c|c|}
\hline \multirow[b]{2}{*}{ Item } & \multicolumn{6}{|c|}{ Protein (\%) } \\
\hline & 3.5 & 4.0 & 6.0 & 8.0 & 10.0 & 12.0 \\
\hline Fat $(\%)$ & 0.1 & 0.1 & 0.1 & 0.2 & 0.2 & 0.2 \\
\hline Lactose $(\%)$ & 5.1 & 5.1 & 5.2 & 5.2 & 5.3 & 5.3 \\
\hline $\mathrm{Ca}^{2+}(\mathrm{mg} / \mathrm{g})$ & 1.3 & 1.4 & 1.9 & 2.5 & 3.0 & 3.6 \\
\hline $\mathrm{DM}(\%)$ & 9.4 & 10.0 & 12.2 & 14.5 & 16.7 & 19.0 \\
\hline \multicolumn{7}{|l|}{$\mathrm{pH}_{\text {milk }}$} \\
\hline $22.5^{\circ} \mathrm{C}$ & 6.84 & 6.78 & 6.70 & 6.63 & 6.59 & 6.55 \\
\hline $43.5^{\circ} \mathrm{C}$ & 6.58 & 6.56 & 6.51 & 6.48 & 6.45 & 6.41 \\
\hline \multicolumn{7}{|l|}{$\mathrm{pH}_{\mathrm{gel}} 1$} \\
\hline $22.5^{\circ} \mathrm{C}$ & 4.45 & 4.42 & 4.48 & 4.54 & 4.56 & 4.57 \\
\hline $43.5^{\circ} \mathrm{C}$ & 4.37 & 4.40 & 4.42 & 4.54 & 4.54 & 4.59 \\
\hline \multicolumn{7}{|c|}{ Fermentation time $^{2}$ (h:min) } \\
\hline $22.5^{\circ} \mathrm{C}$ & $12: 40$ & $12: 40$ & $14: 11$ & $19: 53$ & $25: 35$ & $30: 17$ \\
\hline $43.5^{\circ} \mathrm{C}$ & $3: 34$ & $3: 33$ & $3: 50$ & $3: 56$ & $4: 23$ & $4: 33$ \\
\hline
\end{tabular}


increased buffering capacity. Enriching the casein and whey protein content of skim milk either by membrane filtration or by adding protein powder further increases mineral content. Hence, higher amounts of lactic acid have to be produced to reach the desired $\mathrm{pH}$, resulting in longer fermentation times. Production managers should keep these long fermentation times in mind when fermenting concentrates.

Gel Firmness. The firmness of the set gels measured by penetration tests is shown in Figure $1 \mathrm{~b}$. Increasing the protein content resulted in a nonlinear increase in gel firmness, in agreement with the studies of Abrahamsen and Holmen (1980), Mistry and Hassan (1992), and Schkoda et al. (2001). The greater firm-
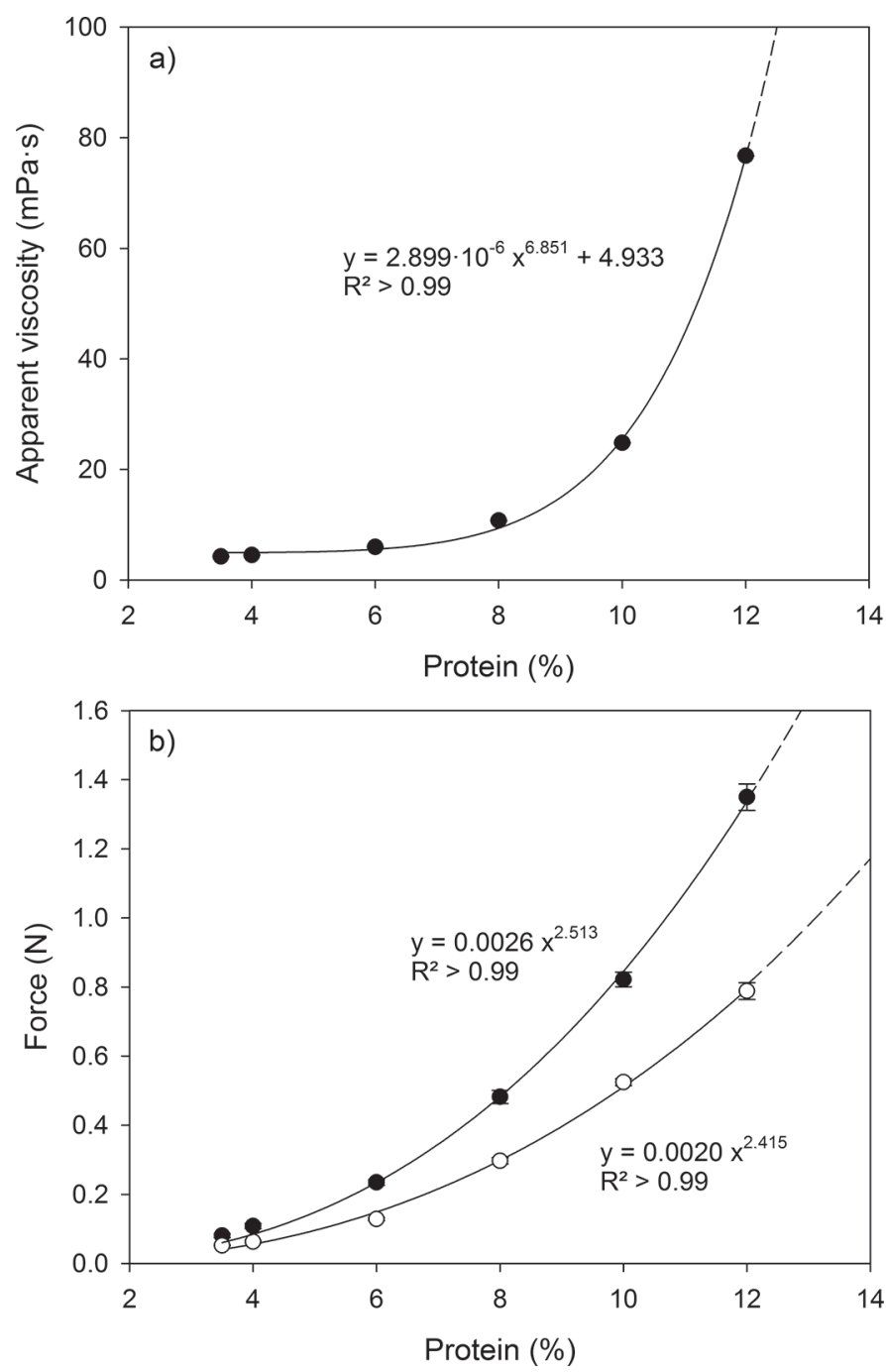

Figure 1. (a) Apparent viscosity of protein-enriched skim milks measured at $10^{\circ} \mathrm{C}$ as a function of protein content; and (b) firmness of the corresponding set gels fermented until $\mathrm{pH} 4.6$ at $22.5^{\circ} \mathrm{C}(\mathrm{O})$ and $43.5^{\circ} \mathrm{C}(\bullet)$ measured by penetration tests at $10^{\circ} \mathrm{C}$. Error bars represent SE. ness can be explained by a higher cross-link density of the gel network caused by greater amounts of protein (Biliaderis et al., 1992; Hinrichs and Keim, 2007). Gel firmness as a function of protein content was fitted by a power function $\left(\mathrm{R}^{2}>0.99\right)$ for fermentations at 22.5 and $43.5^{\circ} \mathrm{C}$, respectively. This is in contradiction to the statements of Lucey (2017), who reported a proportional relationship between casein concentration and gel stiffness. Interestingly, Figure 1 indicates a potential correlation between protein content and apparent viscosity or gel firmness (i.e., before and after fermenting the protein-enriched milks, respectively). However, gels fermented at $43.5^{\circ} \mathrm{C}$ were generally firmer than those fermented at $22.5^{\circ} \mathrm{C}$ with a mesophilic starter culture. At a protein content of $10 \%$ (wt/wt), gels exhibited a firmness of $822 \pm 21 \mathrm{mN}\left(43.5^{\circ} \mathrm{C}\right)$ and $525 \pm 10 \mathrm{mN}$ $\left(22.5^{\circ} \mathrm{C}\right)$. An increase in gel firmness with increasing fermentation temperature was also reported by Aichinger et al. (2003) and Haque et al. (2001). As proposed by Horne (1998), the driving force for the aggregation of casein micelles is hydrophobic association; thus, gel firmness increases with the fermentation temperature. When the gel is cooled after fermentation, hydrophobic interactions decrease and are replaced by noncovalent interactions (hydrogen bonding, dipolar, and electrostatic). However, the primary gel structure formed at the prevailing fermentation temperature remains unchanged (Haque et al., 2001). Our results show that fermented milk gels with $\geq 8 \%$ protein exhibited excessive firmness, which means that the stirring process in large tanks becomes difficult or impossible. In addition, reducing the size of microgel particles is impaired so the mouthfeel of the final product tends to be rough. Because the composition of milk proteins strongly affects gel structure, adjusting the heat treatment and formulation may improve yogurt texture (Sodini et al., 2004; Mahomud et al., 2017). Jørgensen et al. (2015) reported that an increased amount of native whey proteins and optimized heat treatment of the concentrate resulted in Greek yogurt with lower gel firmness and better sensory properties.

\section{Sonication During Fermentation}

Power US was applied during fermentation to evaluate its benefits in terms of further processing; that is, stirring in the tank and breaking up the structure of the milk gel. Protein-enriched milks (10\% protein) were fermented at $43.5^{\circ} \mathrm{C}$ and sonicated from $\mathrm{pH} 5.8$ to 5.1 to cover the period of aggregation. This temperature was chosen because gels from thermophilic fermentations were firmer than those from mesophilic fermentations. Several physical and structural properties of set and stirred yogurts were analyzed. 
Effect on Set Gels. Results from the agitation tests are shown in Figure 2a. The torque required to rotate the vane in the warm set gel directly after fermentation was significantly decreased by sonication. The maximum torque decreased by $75 \%(P<0.001)$ from 7.06 $\pm 0.38 \mathrm{~N} \cdot \mathrm{m}$ (control) to $1.77 \pm 0.06 \mathrm{~N} \cdot \mathrm{m}$ (sonicated). Furthermore, the angle of rotation at which maximum torque occurred and the gel broke was $85 \pm 14^{\circ}$ (control) and $45 \pm 3^{\circ}$ (sonicated). For industrial purposes, such a weakening of the gel would improve the stirring process in the fermentation tank and reduce the agitator power. Sonication also reduced the firmness of the set gels after cooling. Figure $2 \mathrm{~b}$ shows the force recorded to penetrate the set gels at $10^{\circ} \mathrm{C}$. The maximum force to penetrate the control was $896 \pm 23 \mathrm{mN}$. In contrast, the sonicated sample showed much lower but steadily increasing values. Within the linear range up to a penetration depth of approximately $3 \mathrm{~mm}$, the force was reduced by $86 \%$ due to sonication. The sonicated sample showed no local maximum, indicating a damaged 3-dimensional network. Körzendörfer et al. (2017) reported softening in set yogurt gels that were sonicated during fermentation. Firmness of yogurts acidified with both exopolysaccharide (EPS)-producing and non-EPS-producing starter cultures was decreased by $28 \%$ in the aforementioned study. However, sonication was carried out for only 5 min and in an ultrasonic water bath with much lower intensity than the cuphorn type used in this study (Mason, 1998).

The sonicated medium undergoes shear forces, shock waves, and microjets but also noncavitational effects, such as acoustic streaming and mechanical vibration (Ashokkumar et al., 2010). Food matrices can be subjected to both physical and chemical alterations, and versatile applications (e.g., emulsification, homogenization, and depolymerization) of US in food (Chemat et al., 2011; Paniwnyk, 2017) and dairy processing (Chandrapala and Leong, 2015) have been reviewed. In particular, US has been reported to reduce the viscosity of starch solutions (Iida et al., 2008) and milk concentrates (Zisu et al., 2013). Sonication of preheated whey protein solutions breaks down heat-induced aggregates and prevents their reformation (Ashokkumar et al., 2009). Sonochemical cleavage can be caused by mechanical degradation due to collapsed cavitation bubbles or by a chemical reaction of the polymer with radicals generated by US (Chemat et al., 2011). Concerning the acid-induced gelation of milk, the net negative charge of casein micelles decreases during fermentation, resulting in lower electrostatic repulsion. Aggregation and gelation of unheated milk starts at $\sim$ pH 5.0 (Lucey, 2017). In yogurt manufacture, milk is generally heat treated to denature whey proteins that then associate with casein micelles. This results in improved sensory properties; however, because of the higher isoelectric point of $\beta$-lactoglobulin, the gelation point is shifted to $\sim \mathrm{pH} 5.3$ (Lee and Lucey, 2010). At this stage during fermentation, the network is formed and primarily stabilized by hydrophobic association, and therefore prone to be disturbed or disrupted by US-induced shear forces. After sonication (i.e., from $\sim \mathrm{pH} 5.0$ to the end of the fermentation), the casein aggregates contract and broken strands can no longer be regenerated (Hassan et al., 1995). The US treatment in this study was performed from $\mathrm{pH} 5.8$ to 5.1 and extended over a relatively long period. Therefore, further experiments are required to study the effect of different
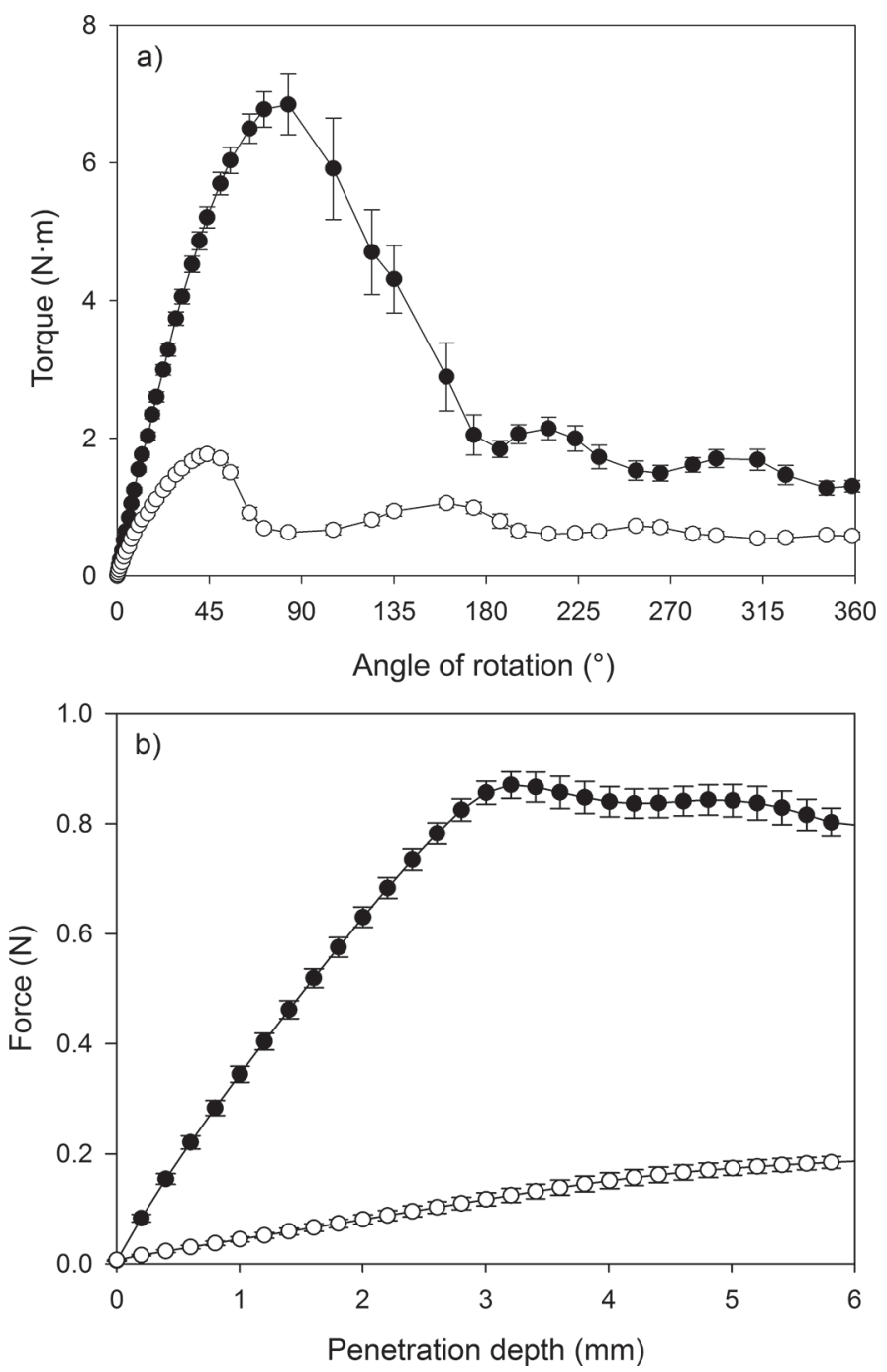

Figure 2. (a) Required torque to stir up and break the set gel directly after fermentation at $43.5^{\circ} \mathrm{C}$; and (b) texture profile analysis of control $(\bullet)$ and sonicated $(\bigcirc)$ set gels measured by penetration tests with a cylindrical plunger (diameter $=10 \mathrm{~mm}$ ) at $10^{\circ} \mathrm{C}$. Error bars represent SE. 
$\mathrm{pH}$ values and the duration of sonication to optimize the US treatment.

Physical Properties and Microstructure. Set gels were subsequently sheared and processed into stirred yogurt. Transmission images were taken of a thin layer of yogurt to evaluate the texture (Figure 3). Black spots represent large protein aggregates; that is, gel fragments that were not broken into micrometerscale particles during the shear treatment. The control sample was grainy and contained large particles up to $3.5 \mathrm{~mm}$. In contrast, the sonicated sample showed an overall smoother texture with a uniform background. This was also reflected by the number of large particles (Table 3), which was reduced by $29 \%$ from 316 \pm 18 (control) to $225 \pm 15$ (sonicated) per $100 \mathrm{~g}$ ( $P$ $<0.001)$. The mean particle size was $1.37 \pm 0.03 \mu \mathrm{m}$ (control) and $1.28 \pm 0.01 \mu \mathrm{m}$ (sonicated) but did not differ significantly. These results are in contrast to previous studies (Nöbel et al., 2016; Körzendörfer et al., 2017), in which sonication during gelation increased the number of large particles. Aggregation of milk proteins and gel formation are sensitive mechanisms that can be disturbed by shaking as well as uniform vibrations (Körzendörfer et al., 2016, 2018). Vibration or sonication in previous studies resulted in compression of the set gel, resulting in a coarser structure in which larger protein clusters were embedded. After shearing, such clusters can still be present in the form of visible lumps (Körzendörfer et al., 2017). We suggest that power US, as applied in the present study, also disturbs gelation but large particles are subsequently broken up again due to cavitation and shear forces.

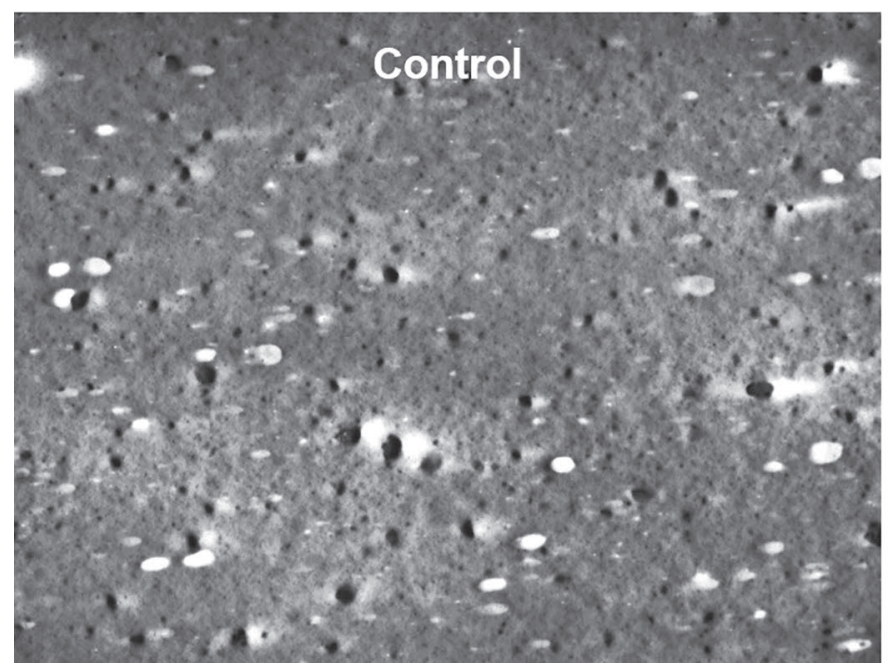

Rheological properties of sonicated stirred yogurts were considerably altered (Table 3 ). Storage modulus, determined by oscillatory measurements, was decreased by $74 \%(P<0.001)$, and phase angle significantly increased, from $13.2^{\circ}$ to $13.5^{\circ}(P<0.001)$, indicating a shift to a more viscous-like character in the sonicated sample. This behavior was confirmed by the flow curves from rotational measurements shown in Figure 4. Shear stresses from the sonicated sample were generally lower. At a shear rate of $100 \mathrm{~s}^{-1}$, the apparent viscosity was reduced by $40 \%$ from $2.53 \pm 0.07 \mathrm{~Pa} \cdot \mathrm{s}$ to $1.52 \pm 0.08$ Pa.s $(P<0.001)$. Nevertheless, the viscosity was still much higher than that of a commercially produced conventional yogurt (4\% protein). In essence, stirred yogurt is a dispersed system that contains serum (acid whey) in which the microgel particles are suspended. From this perspective, yogurt viscosity depends on the viscosity of the outer phase (acid whey), which may be influenced by hydrocolloids or exopolysaccharides. Furthermore, apparent viscosity is heavily influenced by the volume fraction, which is primarily determined by the total protein content and the shape and structure of the microgel particles (Walstra et al., 2006). Based on a high protein content of $10 \%$, our control sample exhibited a high volume fraction, resulting in a product with more solid-like character. Consequently, the strong decrease in viscosity following power US should be linked to a decreased volume fraction.

Power US further altered the size of microgel particles measured by laser diffraction (Table 3). The US treatment resulted in a slightly decreased $d_{10}(P<0.01)$ and increased $d_{90}(P<0.001)$, whereas the mean particle

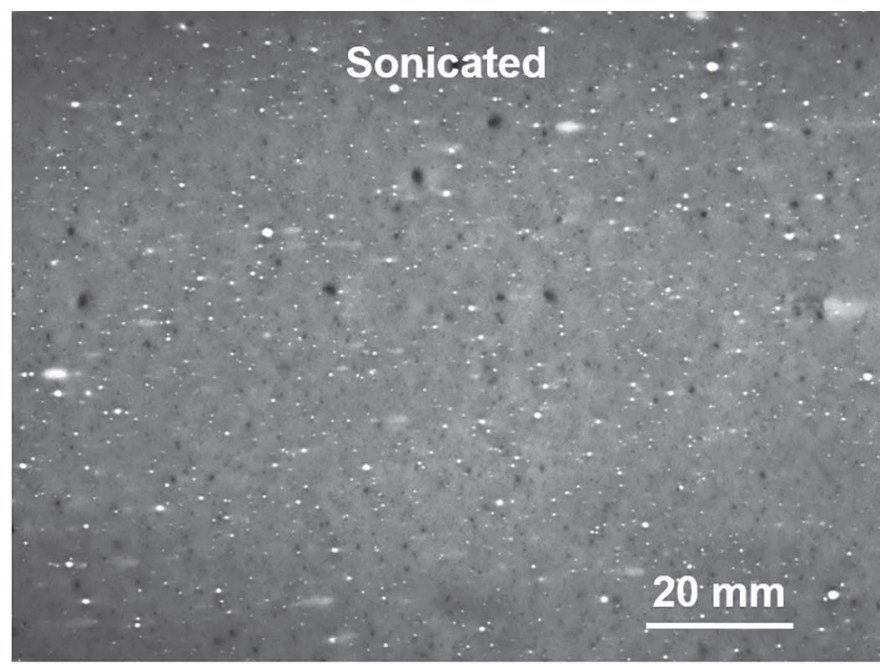

Figure 3. Transmission images $(120 \mathrm{~mm} \times 90 \mathrm{~mm}$, layer thickness of $1.2 \mathrm{~mm}$ ) of stirred yogurts after shearing through a nozzle (diameter $=3 \mathrm{~mm}$, length $=25 \mathrm{~mm}$ ). Each image shows approximately $13 \mathrm{~g}$ of yogurt, at the same scale; black spots represent large, visible particles. 
size $d_{50}$ was unchanged. This broadening of the particle size distribution indicated that sonication did not generally reduce the particle size because larger aggregates were also present. The increased size of some microgel particles $\left(d_{90}\right)$ due to sonication is in accordance with the studies of Nöbel et al. (2016) and Körzendörfer et al. (2017), even though the effects were differently pronounced and depended on further parameters such as sonication $\mathrm{pH}$ and starter culture.

Representative CLSM images of the stirred yogurts are shown in Figure 5. In contrast to the transmission images, which show the macroscopic texture of the stirred yogurts (Figure 3), CLSM images show the microstructure of the homogeneous background. The continuous phase (i.e., the entrapped serum) is black and the microgel is red (the dye associates with the protein). Sonication considerably affected the microstructure. In Figure 5, the control yogurt exhibits a fine-pored structure with high coherence of the proteins forming the discontinuous phase. The serum is predominantly distributed within small cavities. In contrast, the sonicated sample shows a "torn-apart" structure. The aggregated proteins are compact and denser and arranged less coherently. Some microgel particles are completely isolated. As a consequence, the serum is distributed in much larger cavities. The increased proportion of black area (serum) indicates a reduced volume fraction of the microgel particles with reduced water binding. This was further confirmed by our observation that sonication significantly decreased the WHC of the stirred yogurt from $93.4 \pm 0.4 \%$ (control) to $89.3 \pm$ $1.1 \%$ (sonicated; $P<0.001$ ). Both WHC and viscosity

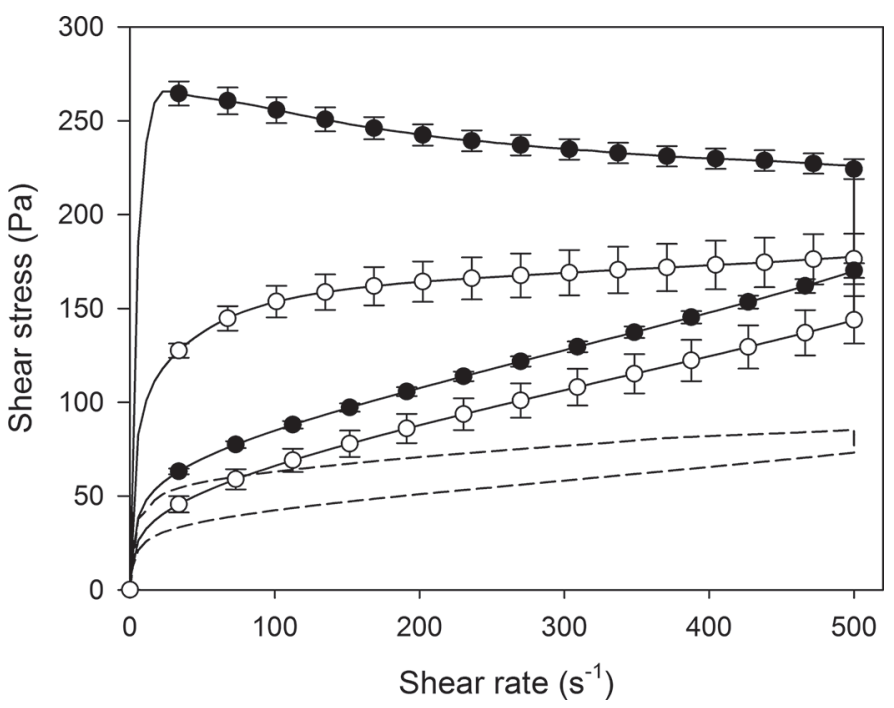

Figure 4. Flow curves of control $(\bullet)$ and sonicated $(\bigcirc)$ stirred yogurts $\left(10 \%\right.$ protein) measured $7 \mathrm{~d}$ after shearing at $10^{\circ} \mathrm{C}$; dashed line: commercial yogurt (4\% protein). Error bars represent SE. 

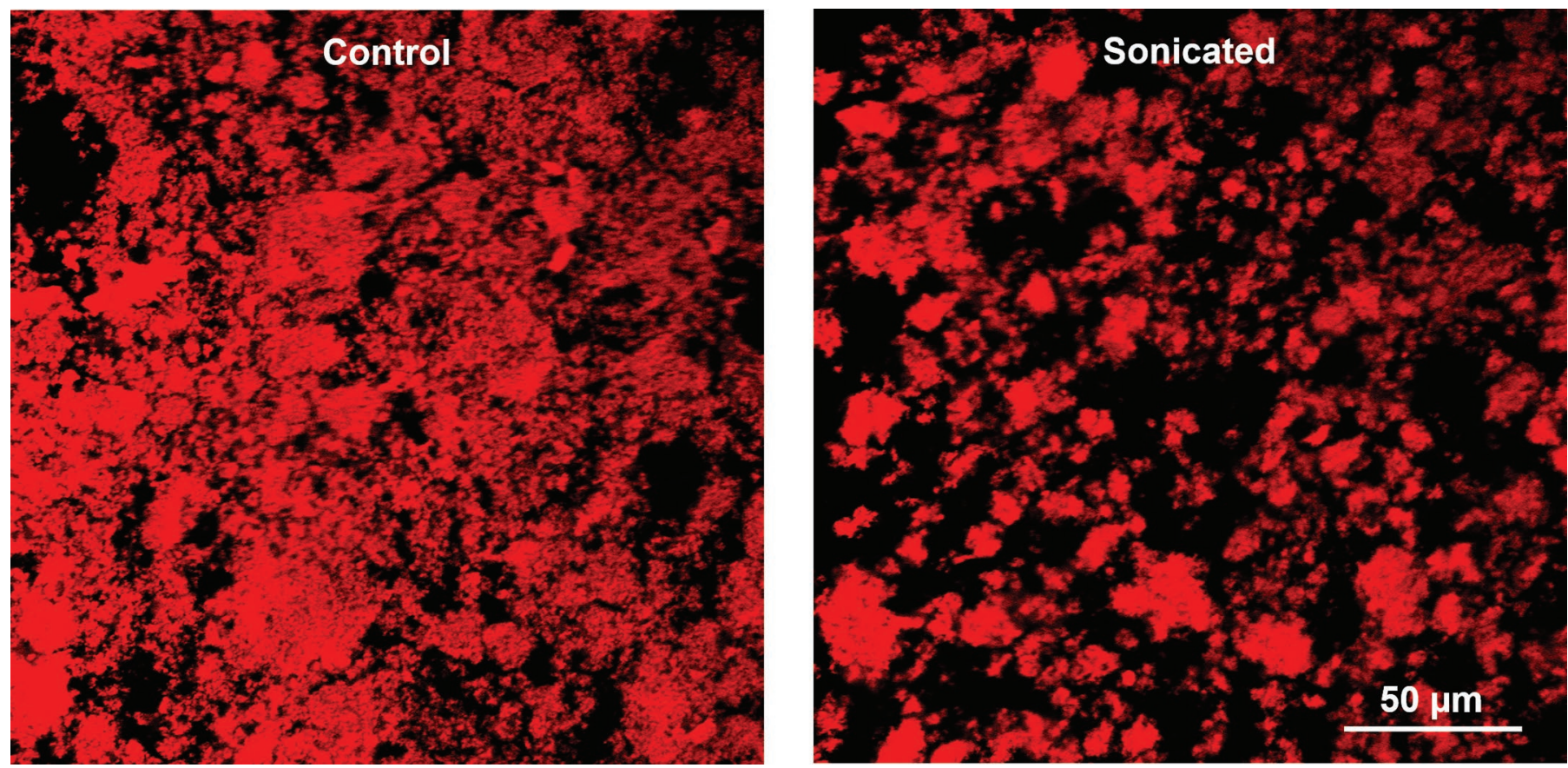

Figure 5. Microstructure of control and sonicated stirred yogurts captured by confocal laser scanning microscopy, at the same scale. Proteins are dyed (red) with rhodamine B (Merck KGaA, Darmstadt, Germany).

are influenced by the volume fraction. Additionally, serum is better retained in a fine-pored structure (Schäfer et al., 2019). The structural properties of the single microgel particles, such as compactness and water content, are also crucial. The CLSM images suggest that reduced WHC could be attributed to an overall lesscohesive structure and more compact microgel particles with a lower water content. The altered microstructure resulted in a decreased volume fraction that was linked to decreased product viscosity. As the transmission (Figure 3) and CLSM (Figure 5) images show, sonication affected structure at both the macroscopic and microscopic levels. The more uniform background of the macrostructure can be explained by the breakup of the microgel into smaller fragments.

Our results and those of earlier studies show that US during fermentation has diverse effects on the set milk gel and the resultant stirred yogurt. One crucial parameter is the energy input, which is dependent on the frequency and amplitude. Lower energy levels, such as those generated by an ultrasonic water bath, disturb gelation, leading to a slightly softer, coarser, and less-branched set gel, so that the stirred product still contains larger aggregates or lumps. In contrast, power US results in considerably softer set gels. The stirred yogurt exhibits a smoother texture and is much less viscous because of the altered microstructure. These findings indicate that it would also be valuable to inves- tigate the application of power US after fermentation to modify flow properties.

\section{CONCLUSIONS}

Because milk gels manufactured at $43.5^{\circ} \mathrm{C}$ were generally firmer than those manufactured at $22.5^{\circ} \mathrm{C}$, the issue of excessive gel firmness is more relevant for thermophilic fermentations (i.e., yogurt production). The strong increase in gel firmness as a function of the protein content of the milk was fitted by power functions for both mesophilic and thermophilic fermentations. Set gels from fermented milk concentrates with $\geq 8 \%$ protein exhibited high gel firmness, making the stirring process in the tank difficult. Gel fragments are firm so further processing steps are also difficult. Applying power US during the fermentation of milk concentrates led to a softening of the set gel, facilitating subsequent stirring. Multiple properties of the stirred yogurt were beneficially altered; in particular, the visually perceived coarseness and apparent viscosity were decreased. The latter effect is promising in terms of designing highprotein products that are easy to consume. This work is considered a feasibility study that shows the applicability of power US during the fermentation of milk concentrates. Investigating sonication parameters such as point of time $(\mathrm{pH})$, duration, and amplitude will help to optimize the treatment. Microbiological analy- 
ses are necessary to examine the effect of power US on the viable cell count, and sensory tests are needed to evaluate mouthfeel characteristics. Power US enables new approaches for the manufacturing of concentrated fermented milks including enhanced processability and novel textures, offering the potential to establish ecological and economic processes without the accumulation of acid whey.

\section{ACKNOWLEDGMENTS}

This IGF Project (AiF 19357 N) of the Research Association of the German Food Industry (FEI, Bonn, Germany) was supported via AiF (Cologne, Germany) within the program for promoting the Industrial Collective Research (IGF) of the German Ministry of Economics and Energy (BMWi, Berlin, Germany), based on a resolution of the German Parliament.

\section{REFERENCES}

Aaltonen, T. 2012. Effect of acidification of whey protein-free precheese retentate on viscosity increase at different concentrations. Lebensm. Wiss. Technol. 47:8-12.

Abrahamsen, R. K., and T. B. Holmen. 1980. Yoghurt from hyperfiltrated, ultrafiltrated and evaporated milk and from milk with added milk powder. Milchwissenschaft 35:399-402.

Abu-Jdayil, B., R. Y. Jumah, and R. R. Shaker. 2002. Rheological properties of a concentrated fermented product, Labneh, produced from bovine milk: Effect of production method. Int. J. Food Prop. 5:667-679.

Agarwal, S., R. L. W. Beausire, S. Patel, and H. Patel. 2015. Innovative uses of milk protein concentrates in product development. J. Food Sci. 80:A23-A29.

Aichinger, P.-A., M. Michel, C. Servais, M.-L. Dillmann, M. Rouvet, N. D'Amico, R. Zink, H. Klostermeyer, and D. S. Horne. 2003. Fermentation of a skim milk concentrate with Streptococcus thermophilus and chymosin: Structure, viscoelasticity and syneresis of gels. Colloids Surf. B Biointerfaces 31:243-255.

Ashokkumar, M., R. Bhaskaracharya, S. Kentish, J. Lee, M. Palmer, and B. Zisu. 2010. The ultrasonic processing of dairy products, an overview. Dairy Sci. Technol. 90:147-168.

Ashokkumar, M., J. Lee, B. Zisu, R. Bhaskarcharya, M. Palmer, and S. Kentish. 2009. Sonication increases the heat stability of whey proteins. J. Dairy Sci. 92:5353-5356.

Biliaderis, C. G., M. M. Khan, and G. Blank. 1992. Rheological and sensory properties of yogurt from skim milk and ultrafiltered retentates. Int. Dairy J. 2:311-323.

Bong, D. D., and C. I. Moraru. 2014. Use of micellar casein concentrate for Greek-style yogurt manufacturing: Effects on processing and product properties. J. Dairy Sci. 97:1259-1269.

Bouchoux, A., B. Debbou, G. Gésan-Guiziou, M.-H. Famelart, J.-L. Doublier, and B. Cabane. 2009. Rheology and phase behavior of dense casein micelle dispersions. J. Chem. Phys. 131:165106.

Brennen, C. E. 1995. Cavitation and bubble dynamics. Oxford University Press, New York, NY.

Brown, M. D., and D. H. Chambers. 2015. Sensory characteristics and comparison of commercial plain yogurts and 2 new production sample options. J. Food Sci. 80:S2957-S2969.

BVL (Bundesamt für Verbraucherschutz und Lebensmittelsicherheit). 1980. §64 LFGB L 01.00-17: Bestimmung des Lactose- und Galactosegehaltes von Bestimmung des Lactose- und Galactosegehaltes von Milch und Milchprodukten; Enzymatisches Verfahren (nach DIN 10344). In Bundesamt für Verbraucherschutz und Lebens- mittelsicherheit, Amtliche Sammlung von Untersuchungsverfahren nach $\S 64$ LFGB, $\S 35$ vorläufiges Tabakgesetz, $\S 28$ b GenTG. Beuth, Berlin, Germany.

Chandrapala, J., and T. Leong. 2015. Ultrasonic processing for dairy applications: recent advances. Food Eng. Rev. 7:143-158.

Chemat, F., Zill-e-Huma, and M. K. Khan. 2011. Applications of ultrasound in food technology: Processing, preservation. Ultrason. Sonochem. 18:813-835.

Chen, G. Q., S. Talebi, S. L. Gras, M. Weeks, and S. E. Kentish. 2018. A review of salty waste stream management in the Australian dairy industry. J. Environ. Manage. 224:406-413.

Dahbi, L., M. Alexander, V. Trappe, J. K. G. Dhont, and P. Schurtenberger. 2010. Rheology and structural arrest of casein suspensions. J. Colloid Interface Sci. 342:564-570.

de Kruif, C. G. 1998. Supra-aggregates of casein micelles as a prelude to coagulation. J. Dairy Sci. 81:3019-3028.

Desai, N. T., L. Shepard, and M. A. Drake. 2013. Sensory properties and drivers of liking for Greek yogurts. J. Dairy Sci. 96:7454-7466.

Erickson, B. E. 2017. Acid whey: Is the waste product an untapped goldmine? Chem. Eng. News 95:26-30.

Fekete, A. A., D. I. Givens, and J. A. Lovegrove. 2013. The impact of milk proteins and peptides on blood pressure and vascular function: A review of evidence from human intervention studies. Nutr. Res. Rev. 26:177-190.

Gogate, P. R., and A. B. Pandit. 2005. A review and assessment of hydrodynamic cavitation as a technology for the future. Ultrason. Sonochem. 12:21-27.

Haque, A., R. K. Richardson, and E. R. Morris. 2001. Effect of fermentation temperature on the rheology of set and stirred yogurt. Food Hydrocoll. 15:593-602.

Hassan, A. N., J. F. Frank, M. A. Farmer, K. A. Schmidt, and S. I. Shalabi. 1995. Formation of yogurt microstructure and threedimensional visualization as determined by confocal scanning laser microscopy. J. Dairy Sci. 78:2629-2636.

Heilig, A., A. Göggerle, and J. Hinrichs. 2009. Multiphase visualisation of fat containing $\beta$-lactoglobulin- $\kappa$-carrageenan gels by confocal scanning laser microscopy, using a novel dye, V03-01136, for fat staining. Lebensm. Wiss. Technol. 42:646-653.

Hinrichs, J. 1999. Influence of volume fraction of constituents on rheological properties and heat stability of concentrated milk. Milchwissenschaft 54:450-454.

Hinrichs, J. 2000. UHT processed milk concentrates. Lait 80:15-23.

Hinrichs, J., and S. Keim. 2007. Process-induced stabilizing bonds in fermented milk products. Milchwissenschaft 62:422-425.

Horne, D. S. 1998. Casein Interactions: Casting light on the black boxes, the structure in dairy products. Int. Dairy J. 8:171-177.

Iida, Y., T. Tuziuti, K. Yasui, A. Towata, and T. Kozuka. 2008. Control of viscosity in starch and polysaccharide solutions with ultrasound after gelatinization. Innov. Food Sci. Emerg. Technol. 9:140-146.

Jørgensen, C. E., R. K. Abrahamsen, E.-O. Rukke, A.-G. Johansen, R. B. Schüller, and S. B. Skeie. 2015. Improving the structure and rheology of high protein, low fat yoghurt with undenatured whey proteins. Int. Dairy J. 47:6-18.

Jørgensen, C. E., R. K. Abrahamsen, E.-O. Rukkeb, T. K. Hoffmann, A.-G. Johansen, and S. B. Skeie. 2019. Processing of high-protein yoghurt-A review. Int. Dairy J. 88:42-59.

Körzendörfer, A., S. Nöbel, and J. Hinrichs. 2017. Particle formation induced by sonication during yogurt fermentation-Impact of exopolysaccharide-producing starter cultures on physical properties. Food Res. Int. 97:170-177.

Körzendörfer, A., P. Temme, S. Nöbel, E. Schlücker, and J. Hinrichs. 2016. Vibration-induced particle formation during yogurt fermentation-Industrial vibration measurements and development of an experimental setup. Food Res. Int. 85:44-50.

Körzendörfer, A., P. Temme, E. Schlücker, J. Hinrichs, and S. Nöbel. 2018. Vibration-induced particle formation during yogurt fermentation-Effect of frequency and amplitude. J. Dairy Sci. 101:3866-3877.

Krzeminski, A., M. Tomaschunas, E. Köhn, M. Busch-Stockfisch, J. Weiss, and J. Hinrichs. 2013. Relating creamy perception of whey 
protein enriched yogurt systems to instrumental data by means of multivariate data analysis. J. Food Sci. 78:S314-319.

Lee, W. J., and J. A. Lucey. 2010. Formation and physical properties of yogurt. Asian-Australas. J. Anim. Sci. 23:1127-1136.

Lucey, J. A. 2017. Formation, structural properties, and rheology of acid-coagulated milk gels. Pages 179-197 in Cheese: Chemistry, Physics and Microbiology. Vol. 1. P. McSweeney, P. Fox, P. Cotter, and D. Everett, ed. Elsevier Academic Press, London, UK.

Mahomud, M. S., N. Katsuno, L. Zhang, and T. Nishizu. 2017. Physical, rheological, and microstructural properties of whey protein enriched yogurt influenced by heating the milk at different $\mathrm{pH}$ values. J. Food Process. Preserv. 41:e13236.

Mason, T. J. 1998. Power ultrasound in food processing-The way forward. Pages 105-126 in Ultrasound in Food Processing. M. J. W. Povey, and T. J. Mason, ed. Blackie Academic \& Professional, London, UK.

Mason, T. J., and D. Peters. 2002. Practical Sonochemistry: Power Ultrasound Uses and Applications. 2nd ed. Woodhead Publishing Limited, Cambridge, UK.

Mawson, A. J. 1994. Bioconversions for whey utilization and waste abatement. Bioresour. Technol. 47:195-203.

Meletharayil, G. H., L. E. Metzger, and H. A. Patel. 2016. Influence of hydrodynamic cavitation on the rheological properties and microstructure of formulated Greek-style yogurts. J. Dairy Sci. 99:8537-8548.

Mistry, V. V., and H. N. Hassan. 1992. Manufacture of nonfat yogurt from a high milk protein powder. J. Dairy Sci. 75:947-957.

Mistry, V. V., and F. V. Kosikowski. 1985a. Fermentation of ultrafiltered skim milk retentates with mesophilic lactic cheese starters. J. Dairy Sci. 68:1613-1617.

Mistry, V. V., and F. V. Kosikowski. 1985b. Growth of lactic acid bacteria in highly concentrated ultrafiltered skim milk retentates. J. Dairy Sci. 68:2536-2543.

Mokoonlall, A., M. Hippich, M. Struch, R. G. Berger, J. Weiss, and J. Hinrichs. 2015. Antioxidant activity of milk suppresses laccase induced radicals and the subsequent modification of acidified milk protein gels. Int. Dairy J. 60:24-31.

Mokoonlall, A., S. Nöbel, and J. Hinrichs. 2016a. Post-processing of fermented milk to stirred products: Reviewing the effects on gel structure. Trends Food Sci. Technol. 54:26-36.

Mokoonlall, A., J. Pfannstiel, M. Struch, R. G. Berger, and J. Hinrichs. 2016b. Structure modification of stirred fermented milk gel due to laccase-catalysed protein crosslinking in a post-processing step. Innov. Food Sci. Emerg. Technol. 33:563-570.

Nöbel, S., N. Ross, K. Protte, A. Körzendörfer, B. Hitzmann, and J. Hinrichs. 2016. Microgel particle formation in yogurt as influenced by sonication during fermentation. J. Food Eng. 180:29-38.

Özer, B. 2006. Production of concentrated products. Pages 128-155 in Fermented Milks. 1st ed. A. Y. Tamime, ed. Blackwell Science Ltd., Oxford, UK.
Özer, B. H., R. A. Stenning, A. S. Grandison, and R. K. Robinson. 1999. Rheology and microstructure of labneh (concentrated yogurt). J. Dairy Sci. 82:682-689.

Paniwnyk, L. 2017. Applications of ultrasound in processing of liquid foods: A review. Ultrason. Sonochem. 38:794-806.

Schäfer, J., K. Sebald, A. Dunkel, T. Hofmann, I. Rosenthal, R. Schuster, Z. Atamer, and J. Hinrichs. 2019. A feasibility study on the pilot scale manufacture of fresh cheese from skim milk retentates without acid whey production: Effect of calcium content on bitterness and texture. Int. Dairy J. 93:72-80.

Schkoda, P., A. Hechler, and J. Hinrichs. 2001. Influence of the protein content on structural characteristics of stirred fermented milk. Milchwissenschaft 56:19-22.

Skriver, A., J. Holstborg, and K. B. Qvist. 1999. Relation between sensory texture analysis and rheological properties of stirred yogurt. J. Dairy Res. 66:609-618.

Sodini, I., F. Remeuf, S. Haddad, and G. Corrieu. 2004. The relative effect of milk base, starter, and process on yogurt texture: A review. Crit. Rev. Food Sci. Nutr. 44:113-137.

Solanki, G., and S. S. Rizvi. 2001. Physico-chemical properties of skim milk retentates from microfiltration. J. Dairy Sci. 84:2381-2391.

Srilaorkul, S., L. Ozimek, and M. E. Stiles. 1989. Growth and activity of Lactococcus lactis ssp. cremoris in ultrafiltered skim milk. J. Dairy Sci. 72:2435-2443.

Tamime, A. Y., M. Hickey, and D. D. Muir. 2014. Strained fermented milks-A review of existing legislative provisions, survey of nutritional labelling of commercial products in selected markets and terminology of products in some selected countries. Int. J. Dairy Technol. 67:305-333.

Tiwari, B. K., K. Muthukumarappan, C. P. O'Donnell, and P. J. Cullen. 2008. Effects of sonication on the kinetics of orange juice quality parameters. J. Agric. Food Chem. 56:2423-2428.

Uduwerella, G., J. Chandrapala, and T. Vasiljevic. 2017. Minimising generation of acid whey during Greek yoghurt manufacturing. J. Dairy Res. 84:346-354.

Uduwerella, G., J. Chandrapala, and T. Vasiljevic. 2018. Preconcentration of yoghurt base by ultrafiltration for reduction in acid whey generation during Greek yoghurt manufacturing. Int. J. Dairy Technol. 71:71-80.

VDLUFA. 2003. Methodenbuch (Handbuch der Landwirtschaftlichen Versuchs- und Untersuchungsmethodik). Vol. 6. 4th ed. R. Bassler, ed. VDLUFA-Verlag, Darmstadt, Germany.

Walstra, P., J. Wouters, and T. Geurts. 2006. Dairy Science and Technology. 2nd ed. CRC Press, Boca Raton, FL.

Zisu, B., M. Schleyer, and J. Chandrapala. 2013. Application of ultrasound to reduce viscosity and control the rate of age thickening of concentrated skim milk. Int. Dairy J. 31:41-43. 